\title{
Foresight and the third mission of universities: the case for innovation system foresight
}

\author{
Piirainen, Kalle A.; Dahl Andersen, Allan ; Andersen, Per Dannemand
}

Published in:

Foresight

Link to article, DOI:

10.1108/FS-04-2014-0026

Publication date:

2016

Document Version

Peer reviewed version

Link back to DTU Orbit

Citation (APA):

Piirainen, K. A., Dahl Andersen, A., \& Andersen, P. D. (2016). Foresight and the third mission of universities: the case for innovation system foresight. Foresight, 18(1), 24-40. https://doi.org/10.1108/FS-04-2014-0026

\section{General rights}

Copyright and moral rights for the publications made accessible in the public portal are retained by the authors and/or other copyright owners and it is a condition of accessing publications that users recognise and abide by the legal requirements associated with these rights.

- Users may download and print one copy of any publication from the public portal for the purpose of private study or research.

- You may not further distribute the material or use it for any profit-making activity or commercial gain

- You may freely distribute the URL identifying the publication in the public portal 


\title{
Foresight and the third mission of universities: The case for innovation system foresight
}

\author{
Kalle A. Piirainen
}

DTU Management Engineering, Technical University of Denmark, Kongens. Lyngby, Denmark

LUT School of Industrial Engineering and Management, Lappeenranta University of Technology, Finland

\section{Per Dannemand Andersen}

DTU Management Engineering, Technical University of Denmark, Kongens. Lyngby, Denmark

\author{
Allan Dahl Andersen \\ Centre for Technology, Innovation and Culture, University of Oslo, Oslo, Norway \\ DTU Management Engineering, Technical University of Denmark, Kongens. Lyngby, \\ Denmark
}

Corresponding author: Kalle A: Piirainen kalpii@dtu.dk

This manuscript has been accepted for publication in Foresight. The manuscript will undergo copyediting, typesetting, and review of the resulting proof before it is published in its final form. Please note that during the production process errors may be discovered which could affect the content, and all disclaimers that apply to the journal apply to this manuscript. A definitive version will be subsequently published. Cite as: Piirainen, K.A., Andersen, P.D., Andersen, A.D. (2016). Foresight and the third mission of universities: The case for innovation system foresight. Foresight, Vol 18, Iss. 1. http://dx.doi.org/10.1108/FS-04-2014-0026 
Abstract:

Purpose - This paper argues that innovation system foresight can significantly contribute to the third mission of universities by creating an active dialog between universities, industry and society.

Design/methodology/approach — This paper's approach is conceptual. We analyse the third mission and relevant literature on innovation systems and foresight to explain how and why foresight contributes to the third mission.

Findings - We propose that foresight contributes to the third mission of universities, particularly to the research and development and innovation dimensions through the development of joint understanding of the agendas and future needs of stakeholders. In addition, foresight enables education to be designed to address identified needs.

Research limitations/implications-The findings are both conceptual and exploratory in nature. Thus, the argument needs further examination through a broader study on foresight in the university-industry context and/or longitudinal research on the outcomes and impact of foresight in this context.

Practical implications - The findings highlight the importance of understanding the systemic nature of innovation and its role in economic development. Universities must understand their role within the larger innovation system to fulfil the potential of economic development and by extension, their third mission.

Originality/value - The paper outlines a novel approach of using innovation system foresight to promote university-industry partnerships and the growth of innovation systems. The paper also contributes to the discussion of the third mission by outlining that mission in practical terms.

Keywords: Foresight; innovation systems; innovation systems foresight; technology transfer; university third mission; university third stream

Article type: Conceptual paper 


\section{Introduction}

As knowledge and knowledge production have become increasingly important for modern societies, the concept of universities' third mission has attracted significant political interest. The third mission entails a variety of activities, including not only (applied) research, development and innovation but also social engagement with the surrounding society that exceed universities' two traditional missions of education and research (Laredo 2007). Universities are expected to assume a more active role in regional and national economic development while facing competition from other public and private higher education and research institutions (Havas 2009). For example, recent developments in the European Union's Research, Development and Innovation (RDI) policy show increasing expectations for universities and other higher education institutions to contribute to the economy. The third mission is an important facet in integrating universities into the surrounding society; however, neither the nature of the mission itself nor its practical implementation have been fully conceptualised (Molas-Gallart \& Castro-Martínez 2007).

In this paper, we argue that foresight is potentially a very fruitful contribution to the third mission of universities. This paper contributes to the conceptualisation of universities' third mission and provides input for the foresight of practitioners and innovation policy makers - especially those interested in how technical universities can contribute more broadly to societal innovation and growth.

At the same time that universities' third mission is gaining attention, the field of foresight is undergoing a two-tracked transformation. First, foresight is developing more solid theoretical foundations as the field moves from being practice-oriented towards becoming an academic discipline. Second, foresight is implementing a systemic and evolutionary understanding of innovation into its concept and applied methodology. 
A recent paper has suggested the concept of 'innovation system foresight' (ISF) as a framework that can advance this two-tracked transformation (Andersen \& Andersen 2014); the authors argue that an increased focus on innovation system foresight can aid this transformation, particularly at the sector level (Andersen et al. 2014), because ISF requires the broad participation of stakeholders and consideration of the critical contextual factors.

In this paper, we unify these two emerging areas of research to explore the preliminary implications of ISF as a process for fostering the third mission of universities. We argue that foresight in general, and ISF in particular, can be instrumental to fulfilling the third mission by creating an active dialog among universities, industry and society. Although our focus is on ISF, much of our argumentation applies to foresight in general and therefore, in some places we may use the terms either interchangeably or side by side.

This paper explores the following research question: what are the contributions of ISF to the third mission of universities? The research approach is conceptual and reflective.

The rest of the paper is structured as follows. The second section outlines the third mission of universities in operational terms. The third section builds on this understanding and examines the general impact of foresight in general, and ISF in particular, leading to a proposed explanation as to how and why foresight contributes to the third mission of universities. The fourth section summarises the main argument and presents this paper's closing remarks.

\section{Universities as an actor in society: The third mission}

During the past decade, the concept of universities' third mission has attracted increased political interest. From the perspective of the knowledge-based economy and 
evolutionary economics, the literature on universities' third mission is associated with general economic development. As (Western) economies are becoming increasingly knowledge-based, great hopes have been established for universities as drivers for knowledge and value creation (Amesse \& Cohendet 2001; Nelles \& Vorley 2010), especially for regional economies (Etzkowitz \& Klofsten 2005). In addition to economic expectations, the social impact of higher education is also high on the European agenda because the European Commission expects higher education to support societal development through continuing education (Crosier et al. 2011).

In general, universities' third mission is considered to be the activities concerned with the generation, use, application and exploitation of knowledge and other university capabilities outside the academic environment (Molas-Gallart \& Castro-Martínez 2007). This is in addition to universities' two traditional 'Humboldtian' missions of academic research and higher education (Rolfo \& Finardi 2012). However, the academic literature on universities' third mission is still emergent and its basic terminology is not yet fully developed. At the moment there are three interpretations of the concept of universities' third mission (Molas-Gallart \& Castro-Martínez 2007). One is associated with a 'third source of income' or a third stream of revenue related to knowledge transfer and licensing intellectual property rights (IPR) (e.g., Meyer \& Tang, 2007) in collaboration with the private sector, private foundations, the European Union, etc. This is in contrast to universities' two traditional sources of income, namely, core appropriations direct from the public and funding from public research councils. Another interpretation associates the third mission with direct activity for the commercial exploitation of universities' resources and research through licensing, consulting and advisory services, and spin-out firms - i.e., technology transfer. A third interpretation is associated with societal outreach. 
Other terms that relate to, overlap with, or are enveloped by the third mission are 'valorisation,' '(technology) transfer,' 'third role' and 'third stream' (Wedgwood 2006; Srinivas \& Viljamaa 2008; Laredo 2007). Among these terms, valorisation and technology transfer focus on one dimension of interaction, i.e., the commercial exploitation of research results. In the North American context, third-mission activities may also be called technology transfer and 'outreach and engagement,' which corresponds to activities aimed at benefiting society. An additional stream of research that is especially related to the technology transfer aspect of the third mission is the 'entrepreneurial university,' which originally investigated universities' role in producing new research-based enterprises (Etzkowitz 1984; Clark 2004; Siegel et al. 2007; Kirby 2006). However, it seems that the scope of the entrepreneurial university construct and that of associated entrepreneurial activities is broadening to cover additional third-mission interactions (Abreu \& Grinevich 2013; Rothaermel et al. 2007).

Despite the relatively broad definition of the third mission, especially in the case of technical universities, it is often understood primarily in terms of the RDI dimension, particularly as technology transfer from research to business through knowledge or Intellectual Property (IP) transfer as well as collaborative or commissioned research and consultancy (Lester 2005). The technology and knowledge transfer stream is the most studied in previous literature (Link et al. 2007; Bozeman 2000; Geuna \& Muscio 2009; Rolfo \& Finardi 2012).

For the purposes of this paper, we adopt the concrete definition from the European Life Long Learning Programme-funded E3M project, which identified thirdmission activities as the following: 1) RDI and technology transfer; 2) continuing education in addition to degree programs, i.e., life-long learning; and 3) social engagement and dialogue with the society through consultancy, expert advice, public 
access to teaching, etc. (E3M 2012) Table 1 illustrates the activities encompassed by universities' third mission.

Table 1. Illustration of third-mission activities (Molas-Gallart et al. 2002; Laredo 2007; E3M 2012), using the example of activities at the Technical University of Denmark (DTU 2013)

Table 1 approximately here

The third mission's emphasis on RDI is conceivably driven by the realities faced by European universities, which struggle with shrinking public budget appropriations, increasing demand for research output, and increasing mutual competition. In this context, a third revenue stream becomes quite attractive. Simultaneously, several countries have implemented new enabling legislation modelled after the Bayh-Dole Act in the United States (Anon 1980), which defaults IPR to the university or other public research organisation instead of the inventor, which in principle enables universities to engage in technology transfer that is more systematic and professional (Clarysse et al. 2007).

In this new context, universities increasingly must justify their existence in society by their output and impact (Lockett et al. 2013). Marginson notes that by default, universities are, at least in part, producers of public goods; ${ }^{1}$ thus, universities always depend on public funding or philanthropy to some extent and should be evaluated by their externalities (Marginson 2007). Consequently, a burgeoning field of research is attempting to define and measure the third-mission or -rank institutions in

1 Public goods are goods or resources that are non-rivalrous and non-excludable (see e.g. Cowen 2008). Codified and published knowledge, e.g., in the form of academic publications, is a typical example of a public good (Stiglitz 1999). 
terms of their success in fulfilling the third mission, for example the E3M project (E3M 2012) and the 'Russell Report' (Molas-Gallart et al. 2002).

\section{Contribution of foresight to the third mission}

In this section we discuss the contribution of foresight and - by extension-ISF to the third mission through a review of the relevant literature. We develop a set of propositions based on understanding the impact of foresight in general and of innovation systems in particular. These bodies of research provide a basis for proposing how and why foresight contributes to the third mission.

\section{Foresight and its impacts}

While discussing foresight in this paper, we refer particularly to ISF, which has been defined as follows: a systematic, participatory, future-intelligence-gathering and medium-to-long-term vision-building process aimed at present-day decisions and mobilising joint actions to improve innovation system performance with the ultimate goal of improving desirable socio-economic performance (Andersen \& Andersen 2014). What sets ISF apart from other foresight is an explicit recognition of the complex nature of innovation and the interplay of actors and institutions.

The practical aim of foresight is often to identify emerging or "generic" technologies that should be pursued in future RDI both to focus resources effectively and to aid economic development (Cariola \& Rolfo 2004). An ultimate goal of foresight is to enable the creation of more value by linking RDI policy more closely to the development of technology and innovation systems (Martin \& Johnston 1999). Within the scope of this endeavour, foresight includes three basic activities: thinking about the future, debating the future and shaping the future (Farhi 2002). These activities also involve three overlapping dimensions of foresight, including the cognitive dimension 
(thinking about the future), the value judgment dimension (debating the future) and the action or implementation dimension (shaping the future).

Synthesising the literature on the benefits or effects of foresight (Yuan et al. 2010; Amanatidou \& Guy 2008; Harper \& Georghiou 2005b; Harper 2013; BelisBergouignan et al. 2001; Havas et al. 2010; Heger \& Boman 2013; Saritas et al. 2013; Fidler 2011; Rohrbeck 2012), we utilise the '5 Cs' of foresight (Martin 1995):

1) The facilitated social process, which may be further supported by expert input, enables the participants to analyse present developments and articulate their views about the future. (Communication)

2) The 'social learning' aspect, combined with argumentation, discussion and negotiation between the process participants and stakeholders, enables mutual learning about participants' own views and objectives relative to those of others. (Communication, Consensus)

3) Social learning changes the participants' mental models, resulting in the perception of 'peripheral vision,' and by extension, fostering behavioural changes. (Commitment)

4) The output of this process is a more-or-less jointly constructed statement about future priorities, actions, goals and/or visions, which leads to action as the collaborative process builds commitment to the outputs on the one hand and between the stakeholders on the other hand, resulting in new actions and initiatives. (Consensus, Coordination)

5) The impact is then 'innovation,' through goal congruence or the strategic alignment and pooling of resources to areas/projects deemed important through both individual organisations and new networks/partnerships ('wiring up the innovation system' or 'structuring' effect) (Concentration, Commitment) 
To use Harper and Georghiou's expression, 'it is almost a truism' that foresight facilitates the success of (national) innovation systems through strategic discourse (Harper \& Georghiou 2005b, p.85). Generally, the impact of creating a joint understanding, an awareness of technological possibilities and a joint vision may surpass the impact of the tangible outcomes of the foresight exercise (Saritas et al. 2013; Belis-Bergouignan et al. 2001). Indeed, it is suggested that foresight should not be judged by the accuracy or volume of its outputs-i.e., reports, presentations and other tangibles_-but instead by its behavioural influence (Salo 2001).

The key message of ISF is that to generate better strategies and a stronger impact, the systemic nature of innovation must be central to foresight thinking (Andersen \& Andersen 2014); that foresight practitioners tend to overestimate the power of foresight as a result of their underestimation of the complexity of innovation is a testament to the latter point (Eriksson \& Weber 2008). Without a systemic understanding of innovation, foresight is bound to have limited impact because of weak conceptual understanding.

The main objective of ISF is to 'strengthen' the innovation system, which involves building, transforming and reorienting the system by removing barriers and promoting learning and innovation activities (Andersen \& Andersen 2014; Martin \& Johnston 1999).

To better understand the contribution of foresight, we propose to use the lens of a functional or process-oriented approach to analyse innovation systems (Bergek et al. 2008). The core of the argument is that an innovation system has key functions or processes that make it a system whose properties are more than the sum of its individual parts and whose participants are more than an arbitrary collection of organisations. Within a given economic framework, innovation systems compete with each other. 
When a new innovation system begins to emerge, it needs to create a space-e.g., a market or user base-where it can exist, often by capturing markets and resources from existing innovation systems. When a system matures, it must maintain that space through internal and external negotiation, the evolution of assets, resources and structures or institutions to fend off other incumbents and new systems (see Figure 1).

Figure 1 approximately here

Figure 1: Functions/drivers for innovation systems (Alkemade et al. 2007; Bergek et al. 2008; K. Piirainen et al. 2013)

The functions have been presented primarily as a descriptive framework for diagnostic analysis to identify systemic and interlocking barriers to innovation that in turn become targets for policy recommendations (Alkemade et al. 2007; Bergek et al. 2008; Bergek 2014). However, the implicit argument is that if functions or processes are "strong" and interact in fruitful ways, they give rise to virtuous circles of development and consequently enable the growth and evolution of an innovation system by fortifying the individual actors and networking among them. Put differently, the functions may provide a fruitful template for data collection and analysis, with the assumption that if not only the key inducement and blocking mechanisms but also the state of the function are identified and diagnosed, foresight is better equipped both to understand how the system is likely to develop and to direct action that enables favourable development.

\section{Two cases of foresight as a third mission activity}

To corroborate the argumentation laid out above, we examine two illustrative cases of university-industry foresight through the lens of their contribution to the third mission. The cases are based on a secondary analysis of existing publications. The first case is the Technical University of Denmark (DTU), whose foresight activities are labelled the 
Sector Development Programme (Andersen 2012). The second case is the Manchester Knowledge Capital collaboration (Manchester: Knowledge Capital 2010), dating back a decade in some form (Harper \& Georghiou 2005a; Harper 2003).

Starting with the DTU case, the following description is based on Andersen (2012) unless otherwise denoted. The main intention of the sector development program was to identify and pursue ideas for the development of business sectors in collaboration with the university, business associations, enterprises and ministries. The aims of this collaboration at the outset were as follows:

1. To define and promote 'strategic' technological areas;

2. To point out barriers and opportunities in the 'framework conditions' for sectors;

3. To support sectors with general consultancy and advisory services; and

4. To secure the foundations and infrastructure of sectors.

The unit presently responsible for the programme is the Office for Innovation and Sector Services, which is located within the university's central administration (DTU 2013; DTU 2014). The office was established in 2011 and the programme followed soon after. The role of the office is both to coordinate foresight activities and facilitate the process. The participants of the process typically include representatives of various enterprises and/or the Danish Industry Association together with relevant experts and researchers from DTU and other research institutions (DTU 2012).

In practice, the processes have consisted of workshops among the invited stakeholders to identify key emerging technologies, barriers and opportunities. The ISF principles are reflected in this example on multiple levels. Reportedly, one of the rationales for the programme was recognition of the open and distributed nature of innovation along a range of different actors, institutions, knowledge bases and infrastructures. The recognition of this systemic nature of innovation led to a 
participative process that involves actors at the sector level. Further examining the rationale of the Sector Development Programme, the programme is closely related to the functions of innovation systems, namely, the rationale of promoting knowledge areas and sectors corresponds to influencing the direction of search and resource mobilisation. Pointing out barriers implies focus on blocking mechanisms and actions to remove them. Finally, focusing on the sector's foundations implies an effort to improve the framework conditions and to enable inducement mechanisms. Furthermore, the inclusive foresight process itself may improve networks and align actors. The expected output is that foresight will contribute to resource mobilisation, direction of search and by extension, capability development. The contribution to the third mission is a dualsided feedback, influencing the direction of knowledge development and search for both industry and academic partners.

The second example is the Manchester Knowledge Capital collaboration, which originally was focused around the Manchester Science Park and the joint interest between the University of Manchester and the Science Park to establish universityindustry relationships and to reinforce third-mission activities in general. Initially, the foresight dimension involved supporting the collaboration between the University of Manchester and the Science Park by building a joint, common vision between the stakeholders and the constituents (Harper 2003).

The initial analysis of the joint vision led to a vision-building exercise that formed 'success scenarios' about how the Manchester region could become a 'Knowledge Capital'. The success-scenario method consists of a series of plenary and parallel workshop sessions to flesh out an inclusive overall vision and targets, along with the aspects and actions necessary to achieve it (Harper \& Georghiou 2005a). 
This setting follows the ISF rationale, but in the regional setting rather than that of the sector. Vision building as such influences the direction of search and as a process may develop networks and align actors, especially in a participatory process. The rationale was to develop a collaboration to attract substantial investment, i.e., to support resource mobilisation (Harper 2003). The aspects considered during the process include (quite broadly) the blocking and inducement mechanisms and the topics included in the scenarios concern the direction of search, knowledge development and resource mobilisation (Harper \& Georghiou 2005a). Accordingly, we propose that the second case is aligned with the functions scheme of analysis because the objectives and design of the study conform to the scheme while contributing to the third mission: the output is a collaboration agenda between the university and the surrounding region.

\section{Contribution of foresight to the third mission}

The common thread between these examples is that both represent university-industry foresight that aims to support the universities' third mission, in particular the RDI dimension. A key similarity is inclusiveness for stakeholders, relatively broad participation and a broad focus on different inducing and blocking mechanisms, or framework conditions for the industry or region. The aim is more-or-less explicitly to support resource mobilisation and knowledge development and to influence the direction of search by highlighting certain substantive targets along with the actions to achieve them. Although the cases do not explicitly follow the functions approach to foresight, the basic patterns of the functions are imprinted on the rationale and design of the process. Therefore, we argue that with due validation, the functions could enable understanding of the impact of foresight on one the hand and could be used as an explicit or implicit framework of data collection and analysis on the other hand. 
Based on the above analysis, we argue further that ISF's contribution to the third mission is linked specifically to the process and to behavioural additionality (Autio et al. 2008) as much as to the outcome. Previous research focused on ISF (Andersen 2012; Andersen et al. 2012; Alkemade et al. 2007) argues that foresight, particularly a 'functions approach,' can play a role in structuring foresight processes aimed at transforming innovation systems by revealing the state and dynamics of the system and thus enabling the actions necessary for transformation. Given the definition and impact of foresight discussed above, foresight is as much a process for developing shared problem perceptions, making differences in expectations explicit and identifying needs (and options) for action, as it is for producing projections of the future. This view is corroborated by the case vignettes, which focused both on identifying the key conditions that enable or inhibit development and on developing a shared understanding of future goals. Thus, we propose that the functions of innovation systems may be a fruitful template to structure and inspire foresight, even though their use would not be as rigorous as in the specific 'functions approach' to foresight (Hekkert et al. 2007; Alkemade et al. 2007).

Table 2 summarises our analysis of the relationship between ISF and universities' third mission. The analysis is based on the assumption that foresight is a participative process that includes not only universities and enterprises but also (possibly) public administration/government, non-governmental organisations (NGOs) and the general public. Contribution to social engagement is especially conditional on broad participation. We can also notice that there is an overlap between RDI and not only social engagement but also foresight activities.

Table 2: Foresight's contribution to universities' third mission

Table 2 approximately here 


\section{Discussion and propositions for further research}

In sum, foresight's primary contribution to universities' third mission, according to this treatise, is that foresight enables participants to better understand each other's interests and agendas. This understanding enables both the immediate exploitation of existing results and future RDI for mutually fruitful directions. Broadly, participative foresight may also support the legitimation of new technologies through the same mechanism. Furthermore, foresight informs those responsible for planning curriculum and continuing education about relevant topics. This contribution mirrors the effects of foresight on the national level, where it is argued that foresight will effectively support the emergence of new innovation systems (Cagnin et al. 2012).

To bring together the strands of the literature, we consider the contribution of foresight to universities' third mission through the lens of the functions of innovation systems. The functions of innovation systems provide insights about why foresight contributes to the third mission, particularly in RDI but also in the education dimension. From another perspective, the functions also serve to inform what aspects of an innovation system can or must be considered during foresight in one form or another. We summarise our key findings as propositions that can be empirically examined in further research.

Judging by the analysis presented above, the process of foresight may prove valuable in terms of creating a shared understanding between academia and not only industry but also the larger society of what research topics and goals are important. We propose that foresight's contributions to the third mission are linked to the foresight process's ability to act as a networking platform and to influence individual actors in terms of attitudes, perceptions and behaviour regarding, e.g., the direction of search for 
technological solutions, directions for RDI activities (knowledge development) and entrepreneurial experimentation.

The literature implies that foresight as a social process includes a two-way feedback channel; it informs the participating researchers about industry's needs and informs industry representatives about researchers' agendas and present knowledge. This qualifies as a contribution to knowledge development with relevance both for the research side and for the direction of search in enterprises. This may very well be true in the examined case vignettes, in which both industry and academia set out to define joint goals and visions. Furthermore, this feedback channel can be beneficial to developing an understanding of knowledge needs in the medium and long term, thus contributing to closing the often-lamented disconnect between research and industrial exploitation. Although this may seem a trivial contribution, the improved understanding of knowledge needs between industry and academia may well be the most desirable understanding for the long-term impact of public research funding. This is not to say that science should only serve the interests of enterprises but instead that identifying common areas of interest could conceivably prove to be fruitful and have an additional impact on RDI policy instruments, such as subsidies. We make the following proposals:

P1: Foresight contributes to universities' third mission through knowledge sharing and negotiation in the foresight process that enable:

Pla: Developing a joint understanding about the 'direction of search' for solutions to present problems; and

P1b: Directing knowledge development, i.e., RDI, in both enterprises and universities, towards future needs

Another function of the foresight process may be the legitimation of novel technologies with enterprises, which may enable more effective transfer of technology 
to markets. The discussion of future challenges and the means to attain them, which is endemic to many foresight processes, may highlight and legitimate the usefulness of present and future research results, thus aiding successful transfer from research to industrial RDI.

P2: Foresight contributes to the legitimation of new concepts and technologies and the transfer of research results to industrial RDI

Although the general portrayal of foresight is often quite positive, recent critical findings (Andersen 2012) suggest that the effectiveness of foresight in contributing to third-mission activities hinges on the participants' commitment to the process and subject matter. The second moderator for the effectiveness of foresight is the absorptive capacity and technological distance between the participants-e.g., research groups and enterprises - which bears on how much the partners are likely to benefit from technology transfer or research collaboration (Kortelainen et al. 2011; Nooteboom et al. 2007).

P3: The effectiveness of foresight is especially moderated by enterprise and university participants':

P3a: Commitment to the process and topic;

P3b: Proximity of technological competence, both in terms of the subject and cognitive distance; and

P3c: Ability to absorb knowledge.

The participative aspects of foresight, insofar as stakeholders other than universities and enterprises are included, also bearing on the legitimation of technology through a two-sided feedback channel. The value judgment dimension of foresight informs what is important to and valued by the participants and enables connections between research, technology and societal goals, thus increasing the legitimacy of RDI. 
P4: The social process of foresight enables mutual understanding of key priorities, goals and values and makes a connection between RDI and important social issues, thus increasing the legitimacy of RDI.

Additionally, we propose that recognising common future interests among industry, society and academia contributes to directing teaching and curriculum development, both for regular programs and for continuing and supplementary education, which in turn contributes to resource mobilisation.

P5: Knowledge sharing and negotiation in the foresight process informs curriculum and continuing education design and supports resource mobilisation.

The limitation of ISF is that it constitutes a balancing act between broad participation and legitimation and commitment to results. With respect to breadth of participation, we anticipate that foresight with relatively narrow, 'invitation-only' participation contributes primarily to developing innovation systems and enterprises and less to the 'softer' aspects of the third mission, such as social engagement.

Bridging the theoretical insights to the practice of foresight, from the standpoint of the third mission the key is not only to develop a shared understanding of priorities as among RDI topics and to develop a legitimate research agenda but also to legitimise existing technologies. The traditional, data-driven approach to priority-setting foresight in the field of RDI has been based on either bibliometrics and systematic reviews, on expert surveys using the Delphi method, or on similar engagement methods, and on combinations thereof; a case in point is the very systematic German science and technology foresight (Cuhls et al. 2009). Although this is not a reflection on the German process or its outcomes, the risk is that heavily expert-focused and methodical foresight alienates both industry and civil society. A contrary example is the participation- 
oriented, vision-building method used in the Manchester case (Harper \& Georghiou 2005a), which approaches setting goals as defining aspirations and a vision, rather than attempting to rigorously extrapolate from present knowledge.

The discussion above suggests that adding participatory methods to facilitate discussion between academia and not only industry but also the wider society may enhance the impact of foresight by improving legitimacy and ownership of the results in the eyes of the stakeholders. In practice, we endorse balancing the methods that focus on evidence and expertise with interaction, using e.g., Popper's framework (Popper 2008). An example is the Lithuanian foresight framework for the RIS3 planning process, which balances the analytical and participatory dimensions by using multiple data sources and methods (Paliokaité et al. 2013).

\section{Conclusion}

The paper set out to explore the potential contribution of ISF to universities' third mission. We started by delineating what the third mission entails in this particular context. Building on that understanding, we discussed foresight within the context of an understanding of the functions of innovation systems. The analysis resulted in five propositions that can be concisely summarised in the following three points. First, foresight contributes to the third mission through informing the direction of RDI. Second, participative foresight, especially ISF, which emphasises broad participation, legitimises shared RDI agendas. However, it is foreseen that commitment to not only the process and subject but also the compatibility of partners moderates the impact of foresight. Finally, we propose that foresight informs curriculum and continuing education design. These propositions relate to the process of foresight and to what might be called behavioural or second-order additionality (Autio et al. 2008). 
The contribution of this paper is twofold. First, it outlines a novel research direction that focuses on foresight as a contribution to universities' third mission. Second, it contributes to the discussion of the operational definition of universities' third mission.

The primary limitation of this research is that it is mainly conceptual. Thus, the first research implication is a need to test the propositions empirically. Second, much of the relevant research is focused on IPR and technology transfer activities, and the outcome of the transfer seem—on average — either unimpressive or ambiguous (Mowery et al. 2001; Mowery et al. 2004; Bozeman 2000). However, the 'softer' thirdmission activities in general have been known to increase the legitimation of a research agenda or to act as a forum to 'advertise' expertise (Perkmann et al. 2013; Perkmann \& Walsh 2009). This suggests that the strata of research that we propose may provide further information about not only the relationships of universities and enterprises but also the impacts of foresight. The topics for further study include descriptive studies and evaluations of foresight exercises run by universities alone and together with industry, along with assessments of the effect of foresight on regions, sectors and economies. Relevant questions include the following: does ISF support universities' third mission and/or the emergence of innovation systems? Answering this question raises a question about which methods and institutional settings have best contributed to the third mission.

As for critical insights, first, from societal and other stakeholders' perspective, the primary incentive for such foresight is the ability to influence the research trajectory or alternatively, to learn the upcoming topics. Many of the foresight exercises conducted in the world, especially in Europe, are publicly sponsored and have the objective of supporting economic development and employment and of highlighting 
economically and/or societally important RDI topics and combinations thereof. For example, foresight has been heavily integrated into the $3^{\text {rd }}$-generation regional Research and Innovation Strategies for Smart Specialisation (RIS3) and the associated S3 platform (European Commission 2014). As set forth above, the European Research and Innovation Strategy for Smart Specialisation (RIS3) strategy platform is one driver of public foresight.

Although the explicit focus of RIS3 strategies is less on sectors and specifically on regions, it has been argued elsewhere that regional economic development is tied to local knowledge and a path for its development (Boschma \& Frenken 2011; Boschma 2014). This supports the argument that ISF makes sense. Additionally, RIS3 strategy processes in various regions employ foresight exercises. For example, Lithuania has developed a national foresight framework (Paliokaité et al. 2013) and in Finland, foresight is included in the missions of both the Regional Councils and the regional Centres for Economic Development, Transport and the Environment, (Andersen et al. 2007), both of which are integrated into the RIS3 processes in accordance with various regional arrangements (e.g., Laitinen \& Lanne, 2012).

The objective of highlighting 'important' RDI topics is not at cross-purposes with foresight as a third-mission activity. For enterprises, the incentive to engage in foresight is similar to that of universities, although the interest in gaining not only complementary knowledge about future RDI but also exploitable research results is more pronounced. The process also provides a venue for discussing more current interests that specifically serve technology or IPR transfer. However, private enterprises tend to be apprehensive about committing to such exercises, and the ownership and results tend to be weak (Andersen 2012; K. A. Piirainen et al. 2013). This apprehension may reflect enterprises guarding their IPR and core capabilities and assets. 
Nevertheless, we propose that this is a question of finding motivated partners and participants rather than an inherent flaw in the concept.

An additional, related topic is how institutionalised foresight interacts with larger public foresight (Weber et al. 2012), that is to say, how individual organisations' foresight can interact with and contribute to broader exercises. The traditional approach is for each organisation to develop its own strategies, whereas collaboration could be even more fruitful. An example of continued joint activity is the Manchester Knowledge Capital (Manchester: Knowledge Capital 2010; Harper 2003; Harper \& Georghiou 2005a) and later, the Corridor Manchester collaboration (Corridor Manchester 2014).

From universities' internal perspectives, the arguments for pursuing thirdmission activities in general range from philanthropy stemming from 'noblesse oblige' and 'giving back to the community that has supported us' to improving the legitimacy of university budget appropriations and subsidies to informed self-interest. The various third-mission activities can be synergistic with the university's two other missions by helping student recruitment, partnering with private enterprises for collaborative projects, and gaining access to data and insights that would be otherwise unobtainable. In closing, we propose that foresight also makes sense from the university perspective because it provides universities in general - and participants in the process in particular — with a better understanding of industry agendas and it enables the recognition of fruitful collaboration opportunities in both the short and medium terms.

\section{References}

Abreu, M. \& Grinevich, V., 2013. The nature of academic entrepreneurship in the UK: Widening the focus on entrepreneurial activities. Research Policy, 42(2), pp.408422. 
Alkemade, F., Kleinschmidt, C. \& Hekkert, M., 2007. Analysing emerging innovation systems: a functions approach to foresight. International Journal of Foresight and Innovation Policy, 3(2), pp.139-168.

Amanatidou, E. \& Guy, K., 2008. Interpreting foresight process impacts: Steps towards the development of a framework conceptualising the dynamics of "foresight systems." Technological Forecasting and Social Change, 75(4), pp.539-557.

Amesse, F. \& Cohendet, P., 2001. Technology transfer revisited from the perspective of the knowledge-based economy. Research Policy, 30(9), pp.1459-1478.

Andersen, A.D. et al., 2014. Exploring Sector Innovation System Foresight in Brazil and Korea: Competencies for Innovation System Transformation, Kongens Lyngby, DK.

Andersen, A.D., 2012. Sectoral innovation foresight - Sector development at the Danish Technical University. In EU-SPRI PhD Spring School.

Andersen, A.D. \& Andersen, P.D., 2014. Innovation system foresight. Technological Forecasting and Social Change, 88, pp.276-286.

Andersen, P.D. et al., 2007. Foresight in Nordic Innovation Systems, Oslo: Nordic Innovation Centre (NICe).

Andersen, P.D. et al., 2012. Innovation-system foresight in practice: A Nordic facilities management foresight. In Proceedings of the 5th ISPIM Innovation Symposium Stimulating Innovation: Challenges for Management, Science and Technology. ISPIM.

Anon, 1980. Patent and Trademark Law Amendments Act (Bayh-Dole Act), United States of America.

Autio, E., Kanninen, S. \& Gustafsson, R., 2008. First- and second-order additionality and learning outcomes in collaborative R\&D programs. Research Policy, 37(1), pp.59-76.

Belis-Bergouignan, M.-C., Lung, Y. \& Héraud, J.-A., 2001. Public foresight exercises at an intermediate level: the French national programs and the experience of Bordeaux. International Journal of Technology Management, 21(7/8), pp.726-738.

Bergek, A. et al., 2008. Analyzing the functional dynamics of technological innovation systems: A scheme of analysis. Research Policy, 37(3), pp.407-429.

Bergek, A., 2014. Technological dynamics and policy: how to derive policy prescriptions. In 3rd Lundvall Symposium: Innovation Policy - Can it Make a Difference?. Ålborg, DK: University of Aalborg, pp. 1-21.

Boschma, R., 2014. Constructing Regional Advantage and Smart Specialisation: Comparison of Two European Policy Concepts. Scienze Regionali, 13(1), pp.5168. 
Boschma, R. \& Frenken, K., 2011. Technological relatedness and regional branching. In H. Bathelt, M. P. Feldman, \& D. F. Kogler, eds. Beyond Territory: Dynamic Geographies of Knowledge Creation, Diffusion and Innovation. Oxon, UK: Routledge, pp. 64-81.

Bozeman, B., 2000. Technology transfer and public policy: a review of research and theory. Research Policy, 29(April 2000), pp.627-655.

Cagnin, C., Amanatidou, E. \& Keenan, M., 2012. Orienting European innovation systems towards grand challenges and the roles that FTA can play. Science and Public Policy, 39(2), pp.140-152.

Cariola, M. \& Rolfo, S., 2004. Evolution in the rationales of foresight in Europe. Futures, 36(10), pp.1063-1075.

Clark, B.R., 2004. Delineating the Character of the Entrepreneurial University. Higher Education Policy, 17(4), pp.355-370.

Clarysse, B. et al., 2007. Academic spin-offs, formal technology transfer and capital raising. Industrial and Corporate Change, 16(4), pp.609-640.

Corridor Manchester, 2014. Strategic Vision to 2020, Manchester, UK.

Crosier, D. et al., 2011. Modernisation of Higher Education in Europe: Funding and the Social Dimension, Brussels, BE.

Cuhls, K. et al., 2009. The methodology combination of a national foresight process in Germany. Technological Forecasting and Social Change, 76(9), pp.1187-1197.

DTU, 2013. DTU Industry Collaboration. Available at: www.dtu.dk/samarbejde [Accessed September 16, 2014].

DTU, 2014. Industry and sector development. Available at:

http://www.dtu.dk/english/Collaboration/Public-sector-consultancy/Industry-andsector-development [Accessed November 3, 2014].

DTU, 2012. Rengфring på slagterier og mejerier i Danmark - Udvikling af fremtidens effektive, ressourcebesparende teknologier, Danish Technical University.

E3M, 2012. Green Paper: Fostering and Measuring “Third Mission” in Higher Education Institutions,

Eriksson, E.A. \& Weber, K.M., 2008. Adaptive Foresight: Navigating the complex landscape of policy strategies. Technological Forecasting and Social Change, 75(4), pp.462-482.

Etzkowitz, H., 1984. Entrepreneurial Scientists and Entrepreneurial Universities in American Academic Science. Minerva, 21(2-3), pp.198-233. 
Etzkowitz, H. \& Klofsten, M., 2005. The innovating region: toward a theory of knowledge-based regional development. $R \& D$ Management, 35(3), pp.243-255.

European Commission, 2014. S3 Platform - Home. Available at: http://s3platform.jrc.ec.europa.eu/home [Accessed September 25, 2014].

Farhi, F., 2002. Thinking, debating and shaping the future: Foresight for Europe, Brussels, BE.

Fidler, D., 2011. Foresight defined as a component of Strategic Management. Futures, 43(5), pp.540-544.

Geuna, A. \& Muscio, A., 2009. The Governance of University Knowledge Transfer: A Critical Review of the Literature. Minerva, 47(1), pp.93-114.

Harper, J.C., 2013. Implementing Foresight Study Results in Policy Action and Measures: EU Experiences. In D. Meissner, L. Gokhberg, \& A. Sokolov, eds. Science, Technology and Innovation Policy for the Future: Potentials and Limits of Foresight Studies. Berlin, Heidelberg: Springer, pp. 219-230.

Harper, J.C., 2003. Improving Links between Tenant Companies and Higher Education Institutions: Exploring Emerging Scenarios for Manchester Science Park, Manchester, UK.

Harper, J.C. \& Georghiou, L., 2005a. Foresight in Innovation Policy: Shared Visions for a Science Park and Business-University Links in a City Region. Technology Analysis \& Strategic Management, 17(2), pp.147-160.

Harper, J.C. \& Georghiou, L., 2005b. The targeted and unforeseen impacts of foresight on innovation policy: the eFORESEE Malta case study. International Journal of Foresight and Innovation Policy, 2(1), p.84.

Havas, A., 2009. Universities and the emerging new players: building futures for higher education. Technology Analysis \& Strategic Management, 21(3), pp.425-443.

Havas, A., Schartinger, D. \& Weber, M., 2010. The impact of foresight on innovation policy-making: recent experiences and future perspectives. Research Evaluation, 19(2), pp.91-104.

Heger, T. \& Boman, M., 2013. Value Creation from Networked Foresighting in the EIT ICT Labs. In The Proceedings of the XXIV ISPIM Conference. Helsinki, FI.

Hekkert, M.P. et al., 2007. Functions of innovation systems: A new approach for analysing technological change. Technological Forecasting and Social Change, 74(4), pp.413-432.

Kirby, D.A., 2006. Creating Entrepreneurial Universities in the UK: Applying Entrepreneurship Theory to Practice. The Journal of Technology Transfer, 31(5), pp.599-603. 
Kortelainen, S. et al., 2011. Dependency between learning and profitability in different industry conditions: a system dynamic simulation. International Journal of Business Innovation and Research, 5(2), pp.229-253.

Laitinen, K. \& Lanne, V., 2012. Satakunta Region: Towards a RIS3 strategy. In Peer Discussion as a Step Towards RIS3. European Commission.

Laredo, P., 2007. Revisiting the Third Mission of Universities: Toward a Renewed Categorization of University Activities? Higher Education Policy, 20(4), pp.441456.

Lester, R.K., 2005. Universities, Innovation, and the Competitiveness of Local Economies: A Summary Report from the Local Innovation Systems Project-Phase I, Cambridge, MA.

Link, A.N., Siegel, D.S. \& Bozeman, B., 2007. An empirical analysis of the propensity of academics to engage in informal university technology transfer. Industrial and Corporate Change, 16(4), pp.641-655.

Lockett, A., Wright, M. \& Wild, A., 2013. The co-evolution of third stream activities in UK higher education. Business History, 55(2), pp.236-258.

Manchester: Knowledge Capital, 2010. Manchester: Knowledge Capital. Available at: http://www.manchesterknowledge.com/home [Accessed November 3, 2014].

Marginson, S., 2007. University mission and identity for a post post-public era. Higher Education Research \& Development, 26(1), pp.117-131.

Martin, B.R., 1995. Foresight in science and technology. Technology Analysis \& Strategic Management, 7(2), pp.139-168.

Martin, B.R. \& Johnston, R., 1999. Technology Foresight for Wiring Up the National Innovation System. Technological Forecasting and Social Change, 60(1), pp.3754.

Meyer, M.S. \& Tang, P., 2007. Exploring the "value" of academic patents: IP management practices in UK universities and their implications for Third-Stream indicators. Scientometrics, 70(2), pp.415-440.

Molas-Gallart, J. et al., 2002. Measuring Third Stream Activities: Final Report to the Russel Group of Universities,

Molas-Gallart, J. \& Castro-Martínez, E., 2007. Ambiguity and conflict in the development of "Third Mission" indicators. Research Evaluation, 16(4), pp.321330 .

Mowery, D.C. et al., 2004. Ivory Tower and Industrial Innovation: University-industry Technology Transfer Before and After the Bayh-Dole Act in the United States, Stanford, CA: Stanford University Press. 
Mowery, D.C. et al., 2001. The growth of patenting and licensing by U.S. universities: an assessment of the effects of the Bayh-Dole act of 1980. Research Policy, 30(1), pp.99-119.

Nelles, J. \& Vorley, T., 2010. From policy to practice: engaging and embedding the third mission in contemporary universities. International Journal of Sociology and Social Policy, 30(7/8), pp.341-353.

Nooteboom, B. et al., 2007. Optimal cognitive distance and absorptive capacity. Research Policy, 36(7), pp.1016-1034.

Paliokaité, A., Martinaitis, Z. \& Reimeris, R., 2013. Foresight Methods for Smart Specialization Strategy Development in Lithuania. In European IFA Academic Seminar. Winterthur: ZHAW Institut für Nachhaltige Entwicklung.

Perkmann, M. et al., 2013. Academic engagement and commercialisation: A review of the literature on university-industry relations. Research Policy, 42(2), pp.423-442.

Perkmann, M. \& Walsh, K., 2009. The two faces of collaboration: impacts of university-industry relations on public research. Industrial and Corporate Change, 18(6), pp.1033-1065.

Piirainen, K. et al., 2013. An Analysis of the Drivers for Emerging Sectoral Innovation Systems in Developing Economies: Cases Tanzania and Vietnam, Helsinki, FI: Aalto University.

Piirainen, K.A., Andersen, A.D. \& Andersen, P.D., 2013. Foresight for sectoral development: Sectoral development as a "Third Mission" activity at the Technical University of Denmark. In European IFA Academic Seminar. Winterthur: ZHAW Institut für Nachhaltige Entwicklung, pp. 1-27.

Popper, R., 2008. How are foresight methods selected? foresight, 10(6), pp.62-89.

Rohrbeck, R., 2012. Exploring value creation from corporate-foresight activities. Futures, 44, pp.440-452.

Rolfo, S. \& Finardi, U., 2012. University Third mission in Italy: organization, faculty attitude and academic specialization. The Journal of Technology Transfer, 37, pp.1-15.

Rothaermel, F.T., Agung, S.D. \& Jiang, L., 2007. University entrepreneurship: a taxonomy of the literature. Industrial and Corporate Change, 16(4), pp.691-791.

Salo, A.A., 2001. Incentives in technology foresight. International Journal of Technology Management, 21(7/8), pp.694-710.

Saritas, O., Pace, L.A. \& Stalpers, S.I.P., 2013. Stakeholder participation and dialogue in foresight. In K. Borch, S. M. Dingli, \& M. Sørgaard Jørgensen, eds.

Participation and Interaction in Foresight: Dialogue, Dissemination and Visions. Cheltenham, UK: Edward Elgar, pp. 35-69. 
Siegel, D.S., Wright, M. \& Lockett, A., 2007. The rise of entrepreneurial activity at universities: organizational and societal implications. Industrial and Corporate Change, 16(4), pp.489-504.

Srinivas, S. \& Viljamaa, K., 2008. Emergence of Economic Institutions: Analysing the Third Role of Universities in Turku, Finland. Regional Studies, 42(3), pp.323-341.

Stiglitz, J.E., 1999. Knowledge as a Global Public Good. In I. Kaul, I. Grunberg, \& M. Stern, eds. Global Public Goods: International Cooperation in the 21st Century. New York, NY: Oxford University Press.

Weber, K.M. et al., 2012. Coping with a fast-changing world: Towards new systems of future-oriented technology analysis. Science and Public Policy, 39(2), pp.153-165.

Wedgwood, M., 2006. Mainstreaming the Third Stream. In I. McNay, ed. Beyond Mass Higher Education: Building on Experience. McGraw-Hill International, pp. 134149.

Yuan, B.J.C., Hsieh, C.-H. \& Chang, C.-C., 2010. National technology foresight research: a literature review from 1984 to 2005. International Journal of Foresight and Innovation Policy, 6(1/2/3), pp.5-35. 
Table 1.

\begin{tabular}{|c|c|c|}
\hline Category & Outputs/outcomes & Examples of activities/services \\
\hline $\begin{array}{l}\text { Research } \\
\text { Development and } \\
\text { Innovation (RDI, } \\
\text { Technology } \\
\text { Transfer) }\end{array}$ & $\begin{array}{l}\text { - Contracts with industry } \\
\text { - Contracts with public } \\
\text { bodies } \\
\text { - Intellectual property } \\
\text { - Spin-offs } \\
\text { - Dissemination }\end{array}$ & $\begin{array}{l}\text { - IP creation and transfer, licensing, } \\
\text { - Student training, capability creation } \\
\text { - Consultancy and advisory, } \\
\text { - Commissioned research, } \\
\text { - Collaborative research, knowledge co- } \\
\text { creation and transfer to industry } \\
\text { - Support for entrepreneurship and } \\
\text { commercialisation of research, spin-offs } \\
\text { - International and domestic partnering and } \\
\text { expert matchmaking services } \\
\text { - Conferences and publications }\end{array}$ \\
\hline $\begin{array}{l}\text { Continuing } \\
\text { education } \\
\text { (Outreach) }\end{array}$ & $\begin{array}{l}\text { - Human resources } \\
\text { - Access to knowledge and } \\
\text { resources }\end{array}$ & $\begin{array}{l}\text { - Industrial Ph.D. programs, capability } \\
\text { creation } \\
\text { - Education and training, MBA programs } \\
\text { - Open access teaching materials, } \\
\text { - Access to scientific infrastructure, } \\
\text { libraries, databases, laboratories, facilities }\end{array}$ \\
\hline $\begin{array}{l}\text { Social } \\
\text { engagement and } \\
\text { dialogue } \\
\text { (Engagement) }\end{array}$ & $\begin{array}{l}\text { - Participation in policy } \\
\text { making } \\
\text { - Involvement in social and } \\
\text { cultural life } \\
\text { - Public understanding of } \\
\text { science }\end{array}$ & $\begin{array}{l}\text { - Campus visits, open days } \\
\text { - Science camps, science fairs } \\
\text { - Museums } \\
\text { - Media and web involvement, dialogue } \\
\text { - Student and staff involvement in cultural } \\
\text { life (externality) } \\
\text { - Consultancy and advisory in policy making }\end{array}$ \\
\hline
\end{tabular}


Table 2.

\begin{tabular}{|c|c|c|}
\hline $\begin{array}{l}\text { Foresight activity (Farhi } \\
\text { 2002) }\end{array}$ & Decomposition & $\begin{array}{l}\text { Contribution to the third } \\
\text { mission }\end{array}$ \\
\hline $\begin{array}{l}\text { Thinking about the future (the } \\
\text { cognitive dimension of } \\
\text { foresight) }\end{array}$ & $\begin{array}{l}\text { Foresight identifies (new) } \\
\text { trends or drivers and trend } \\
\text { breaks to guide decision- } \\
\text { making. } \\
\text { Foresight aims to identify } \\
\text { innovation priorities on the } \\
\text { basis of projections of future } \\
\text { developments in science, } \\
\text { technology, economy and } \\
\text { society }\end{array}$ & $\begin{array}{l}\text { Social engagement and } \\
\text { dialogue, } \\
\text { - Gaining understanding } \\
\text { about the future expectations } \\
\text { of the participants } \\
\text { Indirect contribution to RDI: } \\
\text { - Identifying new trends } \\
\text { through research-based } \\
\text { knowledge and expertise } \\
\text { Continuing education: } \\
\text { - Understanding possible new } \\
\text { skills and knowledge needed } \\
\text { in the future }\end{array}$ \\
\hline $\begin{array}{l}\text { Debating the future (the value } \\
\text { judgment dimension of } \\
\text { foresight) }\end{array}$ & $\begin{array}{l}\text { Foresight aims to encourage } \\
\text { open discussion between the } \\
\text { participants to create a shared } \\
\text { understanding. } \\
\text { Foresight is frequently a } \\
\text { participative process } \\
\text { involving different } \\
\text { stakeholders (e.g., industry, } \\
\text { public authorities, research } \\
\text { organisations, industry } \\
\text { representatives, NGOs) and }\end{array}$ & $\begin{array}{l}\text { Social engagement and } \\
\text { dialogue: } \\
\text { - Insight into the priorities in } \\
\text { the society. } \\
\text { - Legitimation of technologies } \\
\text { - Networking and } \\
\text { investigating partners }\end{array}$ \\
\hline
\end{tabular}




\begin{tabular}{|c|c|c|}
\hline $\begin{array}{l}\text { Foresight activity (Farhi } \\
\text { 2002) }\end{array}$ & Decomposition & $\begin{array}{l}\text { Contribution to the third } \\
\text { mission }\end{array}$ \\
\hline & $\begin{array}{l}\text { the activities can be organised } \\
\text { at different levels, including } \\
\text { the cross-national, national, } \\
\text { sectoral and regional levels. }\end{array}$ & \\
\hline $\begin{array}{l}\text { Shaping the future (the } \\
\text { pragmatic and } \\
\text { implementation-oriented } \\
\text { dimension of foresight) }\end{array}$ & $\begin{array}{l}\text { Foresight aims to identify } \\
\text { possible futures and future } \\
\text { developments, to imagine } \\
\text { desirable futures, and to } \\
\text { identify strategies that } \\
\text { facilitate implementation. }\end{array}$ & $\begin{array}{l}\text { Indirect contribution to RDI } \\
\text { through: } \\
\text { - Identifying research-based } \\
\text { solutions, and } \\
\text { - Researching possible } \\
\text { projects and partners }\end{array}$ \\
\hline
\end{tabular}


Figure 1.

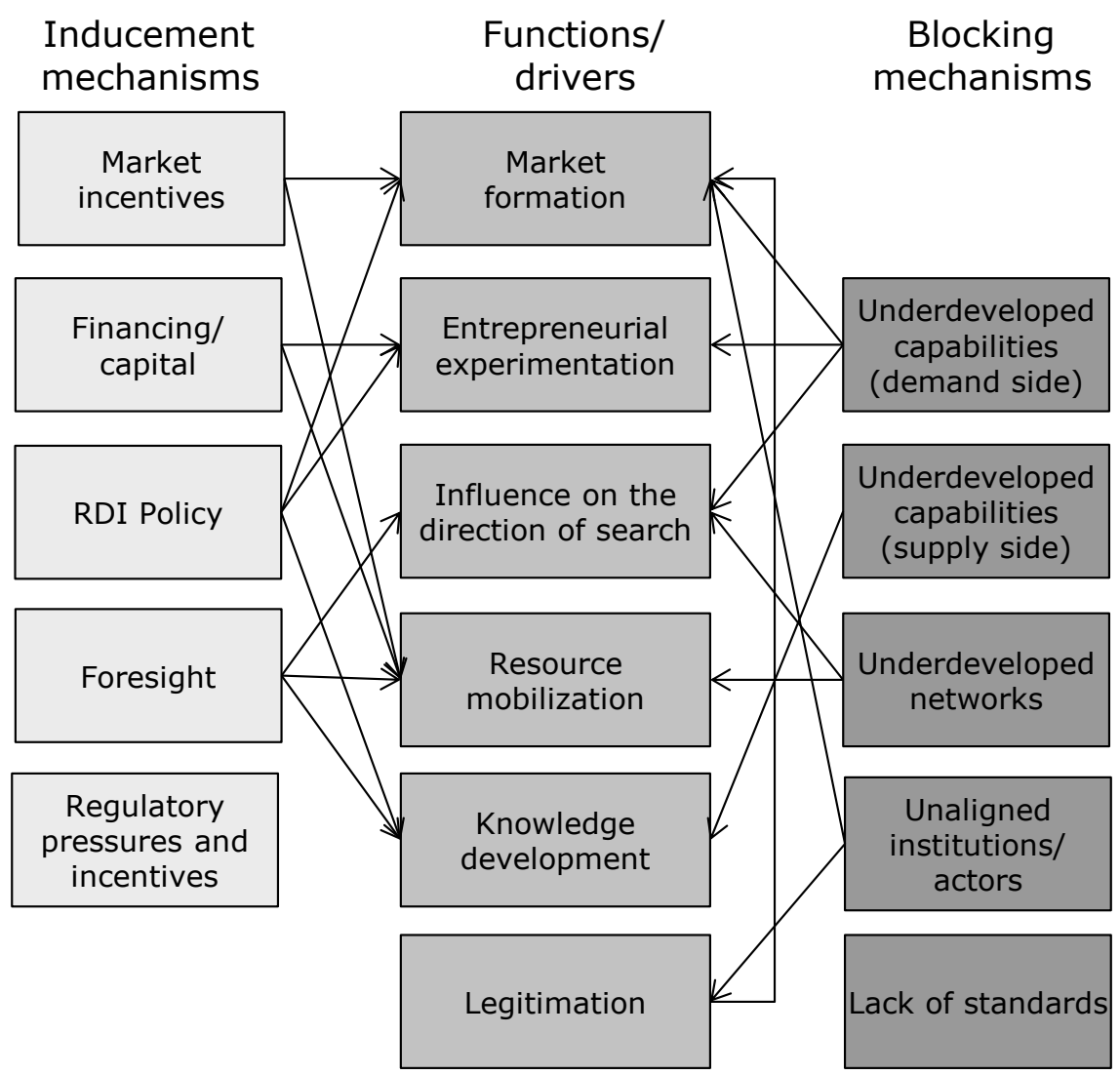

\section{Biographical details}

Kalle A. Piirainen works currently as a Post Doc Researcher on a cluster development project in the North Sea off-shore wind service sector. He is also an Adjunct Professor of Innovation Management at LUT School of Industrial Engineering and Management. His main areas of expertise are Innovation and Technology Management as well as RDI Policy, Strategic Management and Foresight. His doctoral dissertation, accepted with honors, developed and evaluated a method for scenario planning in the context of innovation management. He is on leave of absence from Rambøll Management Consulting, the leading Scandinavian public sector consultancy. His work there specializes in innovation and strategic management, and high-level consulting and research related to innovation policy.

Allan Dahl Andersen has a bachelor in economics from Aalborg University. From the same university he has a master degree in Innovation, Knowledge and Economic dynamics (MIKE). He has an additional master degree (cum laude) in economics from Universiteit van Amsterdam 
with a major in development economics and a minor in institutional economics. Allan did his $\mathrm{PhD}$ in Economics of Innovation with the IKE-group at Aalborg University. His PhD work centered around the role of natural resources in economic development, theoretical issues of building and transforming systems of innovation, and analyzing the evolution of the sugarcanebiofuel industry in Brazil as a (sectoral) natural-resource based innovation system. After his $\mathrm{PhD}$ Allan worked one and half year at the Technical University of Denmark as a Postdoctoral fellow where he worked on exploring and outlining the conceptual linkages between technology foresight and the innovation-system approach.

Per Dannemand Andersen is professor in Technology Foresight and Innovation and heads the Technology and Innovation Management Division. During the latest 15 years his professional interests have focused on three areas: a) Technology foresight, b) Strategy and strategy processes in industrial sectors, and c) Innovation in energy technologies. He has led and participated in numerous externally funded Danish, Nordic and European research and network projects. He has published in journals such as Energy Policy, Technology Analysis \& Strategic, Management, Creativity and Innovation Management, Technovation, and Foresight. He is a member of the board for journals such as The European Journal of Futures Research, EURO Journal on Decision Processes, and International Journal of Energy Technology and Policy. 